\title{
HLA allele distributions and associations in a cohort of LTNPs from China
}

\author{
Mohammad A Rai ${ }^{1 *}$, Stella Chun Hao ${ }^{1}$, Marie-Eve Blais ${ }^{1}, \mathrm{~T}_{\text {Rostron}}{ }^{1}, \mathrm{Y} \mathrm{Zhang}^{2}, \mathrm{KY} \mathrm{Xu}^{2}, \mathrm{H}$ Yan $^{2}$, \\ Andrew J McMichael', T Dong ${ }^{1}$, Sarah Rowland-Jones ${ }^{1}$ \\ From 15th International Conference on Human Retroviruses: HTLV and Related Viruses \\ Leuven and Gembloux, Belgium. 5-8 June 2011
}

\section{Background}

Various studies have shown that HLA polymorphisms are associated with susceptibility/resistance to HIV-1 infection, and therefore influence the rate of disease progression of HIV/AIDS in individuals of different ethnic backgrounds. Association of HLA with HIV/AIDS has been studied extensively within Caucasians and Africans. However, limited data are available from China.

\section{Methodology}

HIV Positive Samples were collected from the SM village in Henan province: SM Cohort. These subjects got infected in the early 90s after taking part in an illegal plasma donation scheme that became contaminated by HIV-1 infection. Our data show that they were infected by a single or a few closely related clade B strains. Control samples collected from a neighboring village. DNA was extracted, HLA-typing done and HLA analysis computed using Arlequin and SAS.

\section{Results}

Genetic profile of the cohorts was obtained. On 1 locus: analysis: HLA A*02 $(\mathrm{P}=0.35)$, HLA $\mathrm{B} * 15(\mathrm{P}=0.02)$ and HLA $B * 44(P=0.02)$ were found to be statistically significant. 2 loci differences include $B * 13 C^{*} 06, B * 13 C^{*} 06$, A*02 C*07, A*24 C*03. 3 loci: A*30 B*13 DRB1*07. Similarly, viral loads and CD4 count associations were computed to find associations co-relating with the HLAs.

\section{Conclusions}

This is the first analysis for HLA distribution amongst LTNPs from China, inferring their HLA co-relates with

\footnotetext{
* Correspondence: mohammad.rai@ndm.ox.ac.uk

${ }^{1}$ MRC Human Immunology Unit, Weatherall Institute of Molecular Medicine, University of Oxford, OX3 9DS, UK

Full list of author information is available at the end of the article
}

a delayed progression to HIV/AIDS. In our cohort, for slow and long-term non-progressors, there is an enrichment of specific HLAs which appear to be associated with delayed disease progression. Next plan is to initiate $\mathrm{T}$ Cell work and also correlate KIR/NK cell responses.

\section{Author details}

'MRC Human Immunology Unit, Weatherall Institute of Molecular Medicine, University of Oxford, OX3 9DS, UK. ${ }^{2}$ Beijing You An Hospital, Capital Medical University, Beijing, PRC.

Published: 6 June 2011

\section{doi:10.1186/1742-4690-8-S1-A84}

Cite this article as: Rai et al:: HLA allele distributions and associations in a cohort of LTNPs from China. Retrovirology 2011 8(Suppl 1):A84.

\section{Submit your next manuscript to BioMed Central and take full advantage of: \\ - Convenient online submission \\ - Thorough peer review \\ - No space constraints or color figure charges \\ - Immediate publication on acceptance \\ - Inclusion in PubMed, CAS, Scopus and Google Scholar \\ - Research which is freely available for redistribution

